\title{
Frontiers in the COVID-19 vaccines development
}

\author{
Ehtisham UI Haq ${ }^{1}$, Jifeng Yu $\mathrm{U}^{2,3^{*}}$ (D) and Jiancheng Guo $3,4,5^{*}$
}

\begin{abstract}
Novel corona virus caused pneumonia first reported in December, 2019 in Wuhan, China was later named COVID-19. Due to its special pathogenicity, COVID-19 transmitted with high speed beyond borders and has significantly affected normal life. Currently, no specific drugs, treatment or vaccines are available. Vaccine development for COVID-19 is a highly complex process involving viral genomic studies, identification of target for vaccine, vaccine design, manufacturing, storage and distribution, preclinical and clinical safety and efficacy studies. The high levels of efforts and global collaboration at this scale is unprecedented. The World Health Organization (WHO) has documented 160 different COVID-19 vaccine candidates as of July 13, 2020 with 26 currently on clinical evaluation while 137 vaccines on preclinical evaluation. COVID-19 vaccine efforts mark the first use of mRNA-type vaccines ever evaluated. Numerous research organizations have successfully initiated clinical evaluation of COVID-19 vaccines. This review aims to summarize the advances and challenges for COVID-19 vaccines development.
\end{abstract}

Keywords: COVID-19, Vaccine development, RNA and DNA vaccine

To the editor,

On December 31, 2019, novel corona virus caused pneumonia was first reported in Wuhan, China. The pathogen was soon identified as a novel corona virus from unknown origin and then was named as "corona virus of 2019" or "COVID-19". With a rapid spread of the virus, WHO declared a global pandemic on March 11, 2020. According to WHO, as of July 14, 2020, almost all countries in the world have been affected with 12,768,307 confirmed cases and 566,654 confirmed deaths due to COVID-19 (https://covid19.who.int/). Its highly infectious and asymptomatic transmission characteristics have made it to a pandemic in a short time [1]. Vaccines are an essential countermeasure urgently needed to control the pandemic.

*Correspondence: Yujifengzzu@163.com; gjc@zzu.edu.cn

${ }^{2}$ The First Affiliated Hospital of Zhengzhou University, \#1 East Jianshe Road, Zhengzhou 450052, China

${ }^{3}$ Academy of Medical and Pharmaceutical Sciences of Zhengzhou University, \#40 Daxue Road, Zhengzhou 450052, China

Full list of author information is available at the end of the article 2-dimension and 3-dimension studies demonstrated COVID-19 virus as RNA stranded virus, surrounded by membrane $(\mathrm{M})$ protein, envelope $(\mathrm{E})$ protein, and the spike (S) structural protein. Genome of virus is highly packed inside nucleocapsid $(\mathrm{N})$ protein which is enveloped by $\mathrm{M}, \mathrm{E}$ and $\mathrm{S}$ protein [2]. Five nonstructural proteins including ORF1ab, ORF3a, ORF7, ORF8, ORF9 and ORF10 play a critical rule in adhesion of virus to host cell and can compromise vaccine efficacy [3]. SARS-CoV-2 shares genetic homology with other coronaviruses found in bats and its closest related human virus, SARS-CoV-1. The spike protein of SARS-CoV-2 has high identity with that of SARS and MERS, which might indicate the similarity of immune evasion mechanism. After publication of the full RNA genetic sequence of COVID-19 from infected patients by Chinese researchers on January 10, 2020 [2], many organizations around the world started to develop vaccines, based on knowledge obtained from SARS and MERS vaccine development, by different means including inactivated whole COVID-19 virus [46], live attenuated virus, adenovirus-based recombinant vector RNA and DNA vaccines [Fig. 1]. As of August

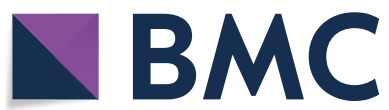

(c) The Author(s) 2020. This article is licensed under a Creative Commons Attribution 4.0 International License, which permits use, sharing, adaptation, distribution and reproduction in any medium or format, as long as you give appropriate credit to the original author(s) and the source, provide a link to the Creative Commons licence, and indicate if changes were made. The images or other third party material in this article are included in the article's Creative Commons licence, unless indicated otherwise in a credit line to the material. If material is not included in the article's Creative Commons licence and your intended use is not permitted by statutory regulation or exceeds the permitted use, you will need to obtain permission directly from the copyright holder. To view a copy of this licence, visit http://creativeco mmons.org/licenses/by/4.0/. The Creative Commons Public Domain Dedication waiver (http://creativecommons.org/publicdomain/ zero/1.0/) applies to the data made available in this article, unless otherwise stated in a credit line to the data. 
24,2020 , WHO documented a total of 160 vaccine candidates against COVID-19, with 26 vaccines currently in clinical evaluation (Table 1) and 137 under pre-clinical evaluation [7]. In order to get herd immunity, an estimated $67 \%$ of population needs to be vaccinated to stop the virus spreading [8]. A vaccine targeting the Spike protein receptor-binding domain (S-RBD) of SARS-CoV-2 induces protective immunity [9] in phase II/III human evaluation, after safety and efficacy results in rhesus macaque [10]. Meanwhile, the Ad5 vectored COVID-19 vaccine targeting the spike glycoprotein showed tolerability and immunogenicity at 28 days post-vaccination (NCT04313127) [11]. A few recent studies demonstrated promising results. The Ad5-vectored COVID-19 vaccine at $5 \times 10^{10}$ viral particles was safe, and induced significant immune responses in the majority of recipients after a single immunization (NCT04341389) [12]. Analysis of 2 randomized phase 1 and phase 2 clinical trials of inactivated vaccine showed that patients had a low rate of adverse reactions and demonstrated immunogenicity (ChiCTR2000031809) [13]. Phase 1/2 single-blind, randomised controlled trial with adenovirus vaccine that expresses the spike protein of SARS-CoV-2 in chimpanzee (ChAdOx1 nCoV-19) showed an acceptable safety profile, and homologous boosting increased antibody responses [14]. Meanwhile clinical trial of mRNA-1273 vaccine results showed vaccination of nonhuman primates induced robust SARS-CoV-2 neutralizing activity, rapid protection in the upper and lower airways, and no pathologic changes in the lung $[15,16]$. Another mRNAbased vaccine BNT162 was initiated phase I/II trial in China (ChiCTR2000034825).

Both live-attenuated vaccines and inactivated vaccines are highly established in product development and manufacturing process but require handling live virus. Meanwhile recombinant protein-based and vector-based vaccines are safe but require epitope selection, antigen design, and vehicle development. Some new-generation vaccine types were not produced on large scale before. RNA and DNA vaccines are two new vaccine technologies currently in focus for COVID-19 vaccine development.

Vaccine development for COVID-19 is a highly complex process involving viral genomic studies, identification of target for vaccine, vaccine design, manufacturing, storage and distribution, preclinical and clinical safety and efficacy studies. The high levels of efforts and global collaboration at this scale is unprecedented. Due to the special nature of this novel virus, vaccine development for COVID-19 seems to be very challenging. However, with the accumulation of more knowledge about the virus and the efforts of global scientific cooperation, the

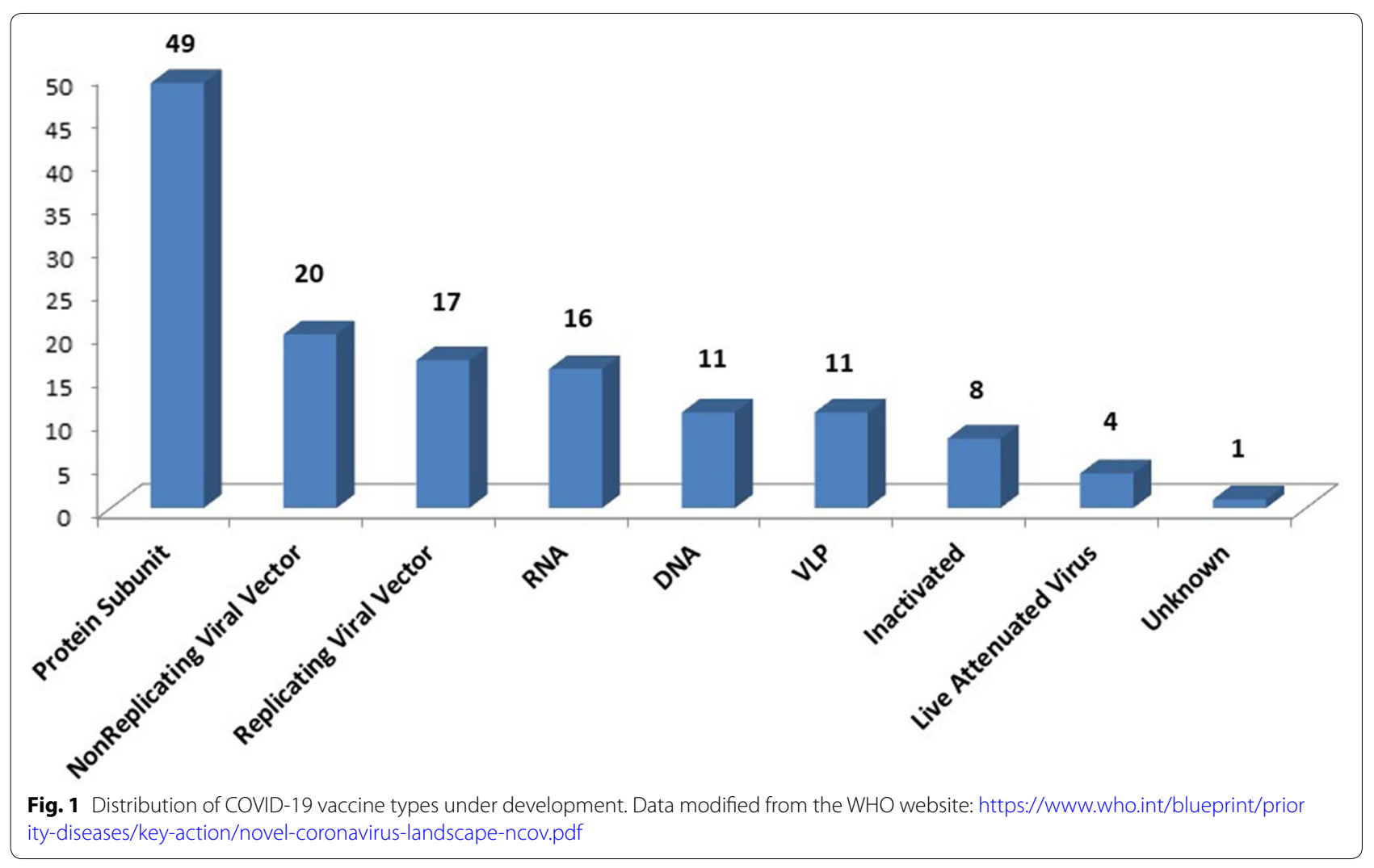




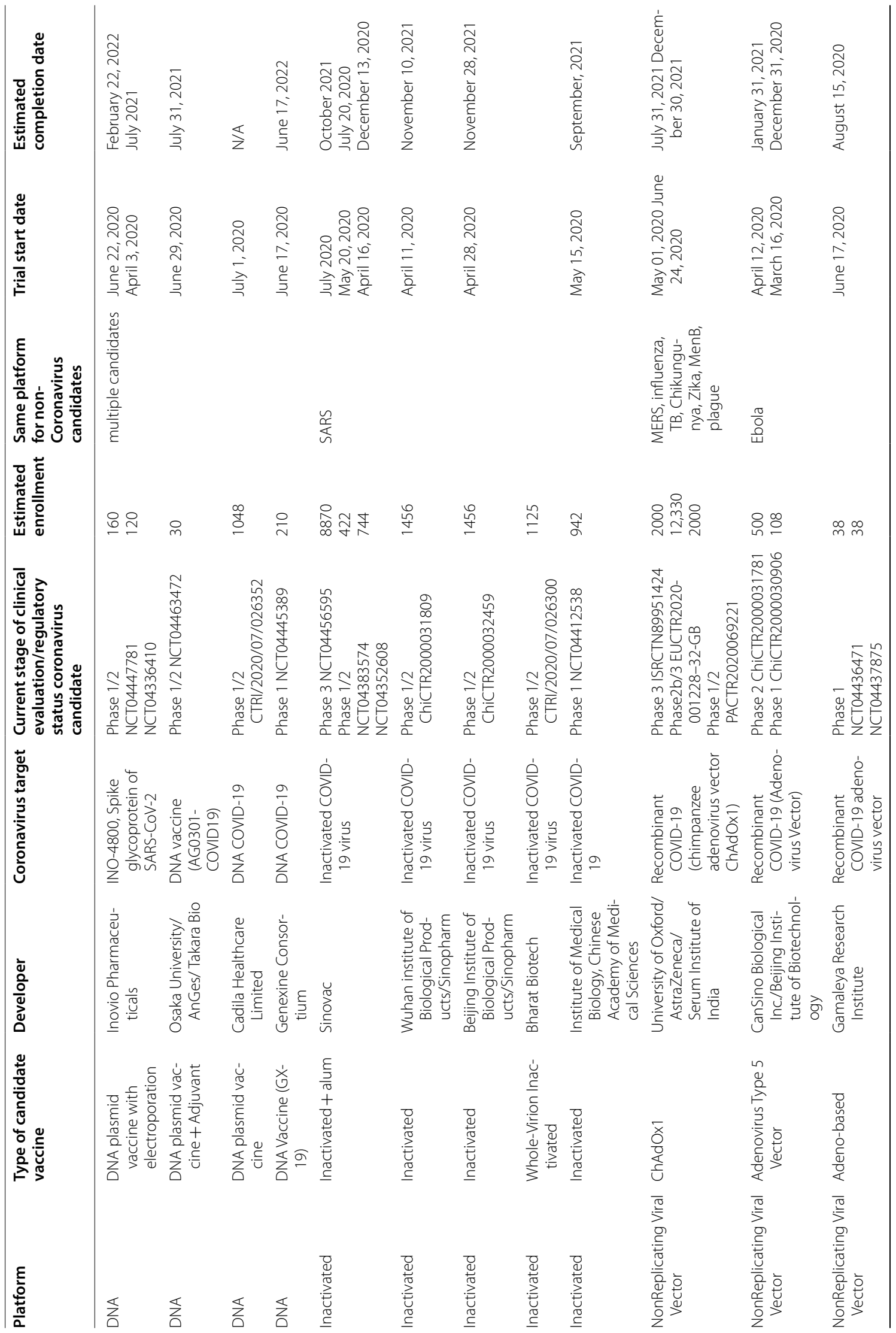




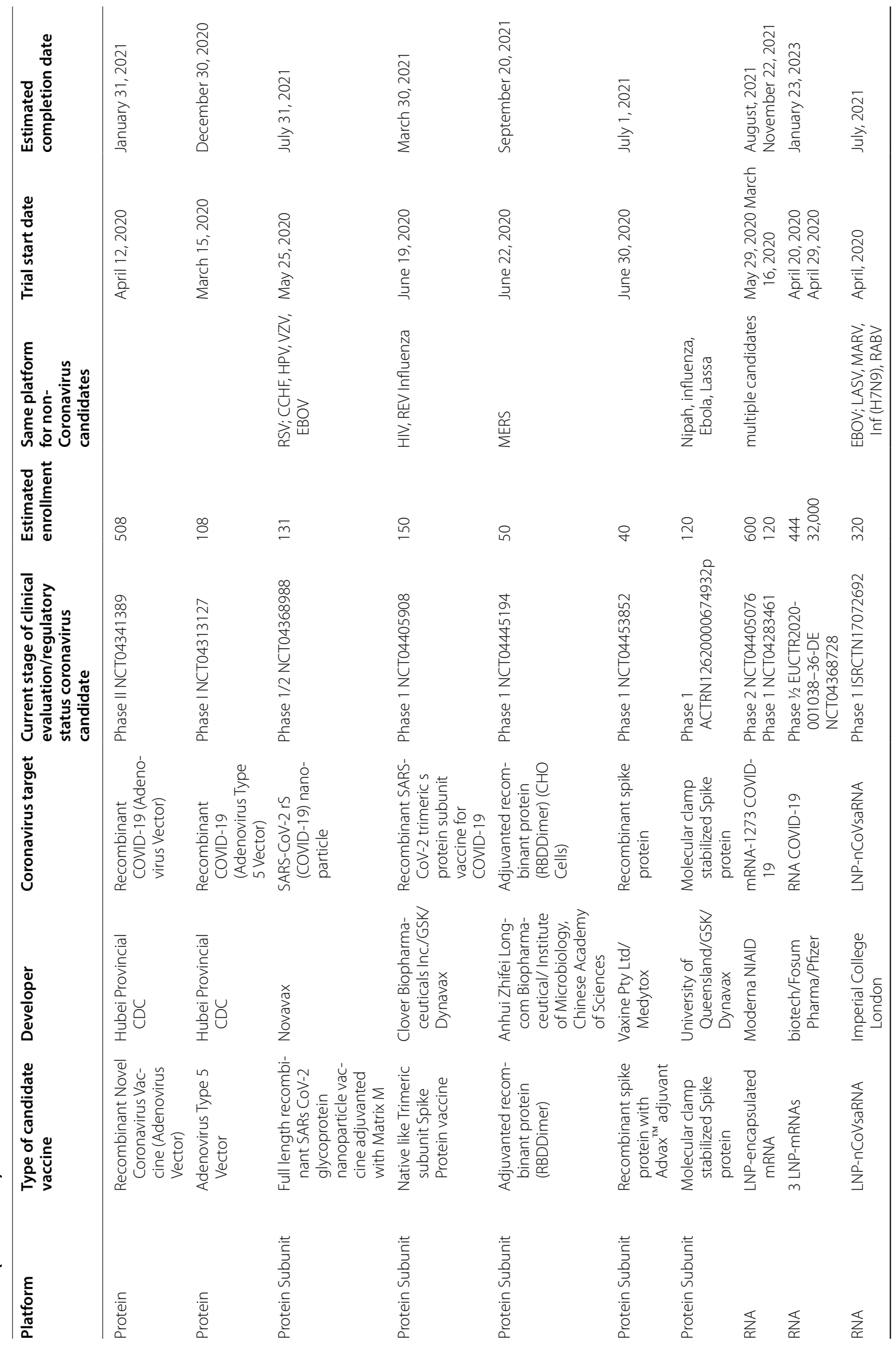




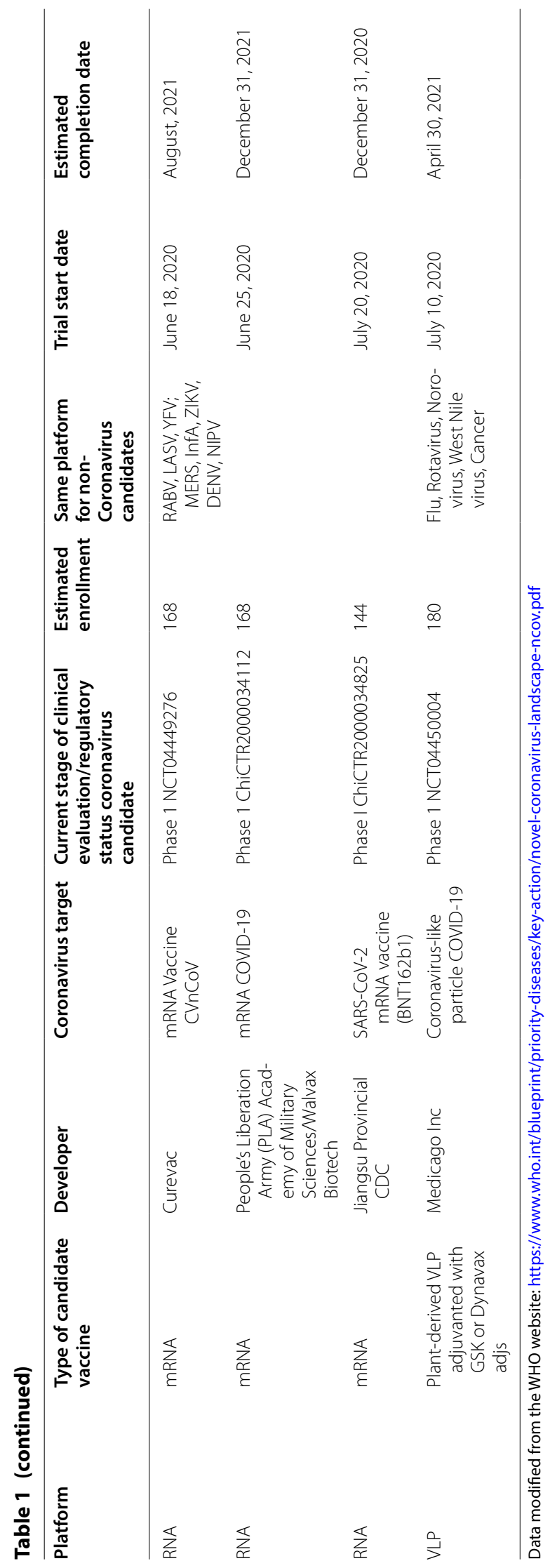


covid-19 vaccine will be successfully developed, and the COVID-19 pandemic will eventually be controlled.

\section{Abbreviations}

COVID-19: Corona virus 2019; WHO: World health organization; SARS: Severe acute respiratory syndrome; MERS: Middle East Respiratory Syndrome.

\section{Acknowledgements}

Not Applicable

\section{Authors' contributions}

All authors contributed to drafting and revising the article and agree to be accountable for all aspects of the work. JY approved the final manuscript. All authors read and approved the final manuscript.

\section{Funding}

This study was funded by the Key Scientific Research Project of Henan Provincial Education Department (20A320062) and Special Talents Project Fund of the First Affiliated Hospital of Zhengzhou University, Zhengzhou, China. The funding bodies did not participate in study design, in data collection, analysis, and interpretation, and in writing the manuscript.

\section{Availability of data and materials \\ Not Applicable.}

Ethics approval and consent to participate

Not Applicable.

\section{Consent for publication}

Not Applicable.

\section{Competing interests}

The authors declare that they have no competing interests.

\section{Author details}

1 School of Basic Health Sciences, Zhengzhou University, No. 100, Science Avenue, Zhengzhou 450001, China. ${ }^{2}$ The First Affiliated Hospital of Zhengzhou University, \#1 East Jianshe Road, Zhengzhou 450052, China. ${ }^{3}$ Academy of Medical and Pharmaceutical Sciences of Zhengzhou University, \#40 Daxue Road, Zhengzhou 450052, China. ${ }^{4}$ Precision Medicine Center of Zhengzhou University, \#40 Daxue Road, Zhengzhou 450052, China. ${ }^{5}$ Department of Molecular Pathology, The Second Affiliated Hospital, Zhengzhou University, \#2 Jingba Road, Zhengzhou 450052, China.

Received: 14 July 2020 Accepted: 30 August 2020

Published online: 03 September 2020

\section{References}

1. Li H, Liu Z, Ge J. Scientific research progress of COVID-19/SARS-CoV-2 in the first five months. J Cell Mol Med. 2020;24(12):6558-700.
2. Zhu N, Zhang D, Wang W, Li X, Yang B, Song J, et al. A novel coronavirus from patients with pneumonia in China, 2019. N Engl J Med. 2020;382(8):727-33.

3. Li F. Structure, function, and evolution of coronavirus spike proteins. Annu Rev Virol. 2016:3(1):237-61.

4. Lurie N, Saville M, Hatchett R, Halton J. Developing Covid-19 Vaccines at Pandemic Speed. N Engl J Med. 2020;382(21):1969-73.

5. Ong E, Wong MU, Huffman A, He Y. COVID-19 coronavirus vaccine design using reverse vaccinology and machine learning. bioRxiv. 2020;64:608.

6. Tian X, Li C, Huang A, Xia S, Lu S, Shi Z, et al. Potent binding of 2019 novel coronavirus spike protein by a SARS coronavirus-specific human monoclonal antibody. Emerg Microbes Infect. 2020;9(1):382-5.

7. DRAFT landscape of COVID-19 candidate vaccines-13 July 2020. https ://www.who.int/blueprint/priority-diseases/key-action/novel-coronaviru s-landscape-ncov.pdf.

8. Randolph HE, Barreiro LB. Herd immunity: understanding COVID-19. Immunity. 2020;52(5):737-41.

9. Yang J, Wang W, Chen Z, Lu S, Yang F, Bi Z, et al. A vaccine targeting the RBD of the S protein of SARS-CoV-2 induces protective immunity. Nature. 2020. https://doi.org/10.1038/s41586-020-2599-8.

10. Chandrashekar A, Liu J, Martinot AJ, McMahan K, Mercado NB, Peter $\mathrm{L}$, et al. SARS-CoV-2 infection protects against rechallenge in rhesus macaques. Science. 2020. https://doi.org/10.1126/science.abc4776.

11. Zhu F-C, Li Y-H, Guan X-H, Hou L-H, Wang W-J, Li J-X, et al. Safety, tolerability, and immunogenicity of a recombinant adenovirus type-5 vectored COVID-19 vaccine: a dose-escalation, open-label, non-randomised, firstin-human trial. Lancet. 2020;395(10240):1845-54

12. Zhu FC, Guan XH, Li YH, Huang JY, Jiang T, Hou LH, et al. Immunogenicity and safety of a recombinant adenovirus type-5-vectored COVID-19 vaccine in healthy adults aged 18 years or older: a randomised, double-blind, placebo-controlled, phase 2 trial. Lancet. 2020;396(10249):479-88.

13. Xia S, Duan K, Zhang Y, Zhao D, Zhang H, Xie Z, et al. Effect of an inactivated vaccine against SARS-CoV-2 on safety and immunogenicity outcomes: interim analysis of 2 randomized clinical trials. JAMA. 2020. https://doi.org/10.1001/jama.2020.15543.

14. Folegatti PM, Ewer KJ, Aley PK, Angus B, Becker S, Belij-Rammerstorfer $\mathrm{S}$, et al. Safety and immunogenicity of the ChAdOx $1 \mathrm{nCoV}-19$ vaccine against SARS-CoV-2: a preliminary report of a phase 1/2, single-blind, randomised controlled trial. Lancet. 2020;396(10249):467-78.

15. Corbett KS, Flynn B, Foulds KE, Francica JR, Boyoglu-Barnum S, Werner $A P$, et al. Evaluation of the mRNA-1273 vaccine against SARS-CoV-2 in nonhuman primates. N Engl J Med. 2020. https://doi.org/10.1056/NEJMo a2024671.

16. van Doremalen N, Lambe T, Spencer A, Belij-Rammerstorfer S, Purushotham JN, Port JR, et al. ChAdOx1 nCoV-19 vaccination prevents SARS-CoV-2 pneumonia in rhesus macaques. bioRxiv. 2020. https://doi. org/10.1101/2020.05.13.093195.

\section{Publisher's Note}

Springer Nature remains neutral with regard to jurisdictional claims in published maps and institutional affiliations.

Ready to submit your research? Choose BMC and benefit from:

- fast, convenient online submission

- thorough peer review by experienced researchers in your field

- rapid publication on acceptance

- support for research data, including large and complex data types

- gold Open Access which fosters wider collaboration and increased citations

- maximum visibility for your research: over 100M website views per year

At BMC, research is always in progress.

Learn more biomedcentral.com/submissions 